\title{
Regulation and symbiotic significance of nodulation outer proteins secretion in Sinorhizobium fredii $\mathrm{HH} 103$
}

Correspondence

Francisco Javier Ollero

fjom@us.es

Received 27 December 2007

Revised 23 February 2008

Accepted 4 March 2008

\author{
Francisco Javier López-Baena, José María Vinardell, \\ Francisco Pérez-Montaño, Juan Carlos Crespo-Rivas, \\ Ramón A. Bellogín, $M^{a}$ del Rosario Espuny and Francisco Javier Ollero \\ Departamento de Microbiología, Facultad de Biología, Universidad de Sevilla, Sevilla, Spain
}

\begin{abstract}
In this work we show that the Sinorhizobium fredii $\mathrm{HH} 103 \mathrm{tts} /$ gene is essential for the expression of the tts genes and secretion of nodulation outer proteins (Nops). Moreover, we demonstrate for the first time, to our knowledge, that the nod box preceding $t t s /$ is necessary for Nops secretion. Ttsl is responsible for the transcriptional activation of nopX, nopA, rhcJ and rhcQ. We confirm that the $S$. fredii $\mathrm{HH} 103 \mathrm{tts} /$ gene is activated by NodD1 and repressed by NoIR. In contrast, NodD2 is not involved in the regulation of tts/ expression. Despite the dependence of expression of both tts/ and nodA on NodD1 and flavonoids, clear differences in the capacity of some flavonoids to activate these genes were found. The expression of the $t t s /$ and nodA genes was also sensitive to differences in the $\mathrm{pH}$ of the media. Secretion of Nops in the tts $/$ mutant could not be complemented with a DNA fragment containing the tts/ gene and its nod box, but it was restored when a plasmid harbouring the ttsl, rhcC2 and y4xK genes was transferred to the mutant strain. The symbiotic effect of Nops secretion was host-dependent but independent of the type of nodule formed by the host legume. Nops are beneficial in the symbiosis with Glycine max and Glycyrrhiza uralensis, and detrimental in the case of the tropical legume Erythrina variegata.
\end{abstract}

\section{INTRODUCTION}

Rhizobia are soil alphaproteobacteria able to establish symbiotic associations with many legumes. This symbiosis leads to the formation of specialized structures called nodules on the roots, and in several cases also in the stems of the host plant. Within these nodules, rhizobia differentiate into nitrogen-fixing bacteroids that are able to reduce atmospheric nitrogen to ammonia. This ammonia can be assimilated by the plant and used for growth and development. In exchange, the host plant provides the bacteria with a carbon source and an appropriate environment that stimulates their growth.

The nodule organogenesis process requires the exchange of symbiotic signals between both members of the symbiosis. Flavonoids exuded by legume roots are recognized by the rhizobial protein NodD, which in turn binds to specific and conserved sequences, called nod boxes, and activates

Abbreviations: $\alpha$, Statistical significance of the differences observed using the Mann-Whitney non-parametric test; LCO, lipochitin oligosaccharide; Nops, nodulation outer proteins; T3SS, type III secretion system.

The GenBank/EMBL/DDBJ accession number for the $t$ ts/ sequence of Sinorhizobium fredii $\mathrm{HH} 103$ is AY184383. the transcription of the nod genes. These genes encode enzymes responsible for the biosynthesis and secretion of the lipochitin oligosaccharides (LCOs), also called Nod factors. These molecules are recognized by the plant and play an important role in triggering the initiation of nodule organogenesis.

Bacterial surface structures such as exopolysaccharides, lipopolysaccharides and capsular polysaccharides, or type III-secreted proteins, are also important for nodulation and host-range determination (Broughton et al., 2000; Perret et al., 2000).

Some Gram-negative bacterial strains possess a specialized apparatus for protein secretion called the type III secretion system (T3SS). The type III secretion apparatus is formed by about 20 proteins, many of them homologous to proteins involved in the biosynthesis of the flagellum. Symbiotic and pathogenic bacteria use the T3SS to deliver proteins into the eukaryotic host cell (Pallen et al., 2003).

Plant-pathogenic bacteria such as Pseudomonas and Xanthomonas secrete harpins and avirulence proteins through the T3SS. Harpins are probably translocated to the extracellular space, inducing disease in susceptible 
plants. Avirulence proteins are translocated into the host cytoplasm and are involved in the hypersensitive response (HR) in resistant plants (Galan \& Collmer, 1999). Some of the genes involved in the biosynthesis of the machinery of the type III secretion apparatus are well conserved among plant-pathogenic bacteria, and have been named hrp for hypersensitive response and pathogenicity. Genes homologous to hrp genes have been found in some rhizobia, such as Rhizobium sp. NGR234 (Viprey et al., 1998), Sinorhizobium fredii HH103 (de Lyra et al., 2006), S. fredii USDA257 (Krishnan et al., 2003), Mesorhizobium loti MAFF303999 (Kaneko et al., 2000) and Bradyrhizobium japonicum USDA110 (Göttfert et al., 2001). Genes responsible for the biosynthesis of the rhizobial T3SS are organized in the $t t s$ region, which also contains genes that encode secreted proteins collectively known as nodulation outer proteins (Nops). To date, eight secreted proteins have been identified: NopA, NopB, NopC, NopD, NopL, NopM, NopP and NopX (Ausmees et al., 2004; Bartsev et al., 2003; Deakin et al., 2005; Krishnan, 2002; Lorio et al., 2004; Rodrigues et al., 2007; Saad et al., 2005; Skorpil et al., 2005). Recently, eight proteins have been found to be type III-secreted in B. japonicum; one of them, GunA2, has been identified as an endoglucanase (Süss et al., 2006).

Despite type III-dependent secretion requiring the presence of flavonoids and the NodD protein, only one gene of the tts region, the ttsI gene, is preceded by a nod box. In Rhizobium sp. NGR234, the expression of ttsI is induced by flavonoids and depends on the transcriptional activator NodD1 (Marie et al., 2004). In the case of B. japonicum, the presence of NodW is also needed (Krause et al., 2002). Amino acid sequence analysis shows that TtsI shares characteristics of two-component response regulators (Marie et al., 2004), and it has been proposed as an intermediary in the regulatory cascade between NodD1 and T3SS-related genes (Viprey et al., 1998). TtsI seems to regulate the expression of some genes by binding to specific promoter sequences called tts boxes (Krause et al., 2002).

Inactivation of ttsI in Rhizobium sp. NGR234 abolishes Nops secretion and affects the symbiosis in a hostdependent manner (Marie et al., 2004). A similar phenotype has been reported in mutant strains of $S$. fredii USDA257 and HH103 that contain a non-functional secretion machinery (Bellato et al., 1997; de Lyra et al., 2006; Meinhardt et al., 1993).

In this work, we report a complete analysis of the transcriptional regulation of $t t s I$ and other $S$. fredii $\mathrm{HH} 103$ genes that belong to the $t$ ts region. We also show how the inactivation of the ttsI gene and its nod box blocks Nops secretion and alters, positively or negatively, the capacity of $S$. fredii HH103 to nodulate some of its host legumes.

\section{METHODS}

Microbial and molecular techniques. Bacterial strains and plasmids used in this work are listed in Table 1. Sinorhizobium strains were grown at $28{ }^{\circ} \mathrm{C}$ on tryptone yeast (TY) medium (Beringer, 1974) or yeast extract mannitol (YM) medium (Vincent, 1970). Escherichia coli strains were cultured on Luria-Bertani (LB) medium (Sambrook et al. 1989) at $37^{\circ} \mathrm{C}$. When required, the media were supplemented with the appropriate antibiotics as described by Lamrabet et al. (1999). Flavonoids were dissolved in ethanol and used at $1 \mu \mathrm{g} \mathrm{ml}^{-1}$, which gave final concentrations between $3.0 \mu \mathrm{M}$ (quercetin) and $6.2 \mu \mathrm{M}$ (umbelliferone). Plasmids were transferred from E. coli to Sinorhizobium strains by conjugation, as described by Simon (1984), using plasmid pRK2013 as helper.

Assays for $\beta$-galactosidase activity in liquid bacterial cultures on YM media were carried out as described by Miller (1972). Bacterial cultures at $\mathrm{OD}_{660} 0.8-1.0$ were diluted 100 -fold before the addition of flavonoids to ensure that bacterial cultures had an $\mathrm{OD}_{660}$ in the range $0.15-0.30$ when $\beta$-galactosidase activity was measured $(16 \mathrm{~h}$ after induction). When necessary, the $\mathrm{pH}$ of the YM medium was buffered to $\mathrm{pH} 6$ with MES $(20 \mathrm{mM})$, or to $\mathrm{pH} 7$ or 8 with HEPES $(20 \mathrm{mM})$.

Recombinant DNA techniques were performed according to the general protocols of Sambrook et al. (1989). For hybridization, DNA was blotted to Hybond-N nylon membranes (Amersham), and the DigDNA method of Roche was employed according to the manufacturer's instructions. PCR amplifications were performed as described previously (Vinardell et al., 2004a). Primer pairs used for amplification of the $S$. fredii $\mathrm{HH} 103 \mathrm{ttsI}$, nodD2 and nopA genes were, respectively: y4xiF (5'-TAATCAGCCTGGCTGACA) and y4xiR (5'AACAGAACGAGCGCGTAGA); D2d (5'-CTAACCAAGCCGGAGGA) and D2r (5'-CCGAAGCCGTGTACCA); fylsecF (5'-CCAGGGAGTCCAGATCGTGCA) and fylsecR (5'-GAGGCGTGGTTTACCGATCGA). The NCBI BLAST program was used for homology searches. Plasmids pMUS741 and pMUS746 were obtained, respectively, by cloning a $1.4 \mathrm{~kb}$ PCR fragment containing the $t$ s I gene and its nod box and a $1.4 \mathrm{~kb}$ PCR fragment containing the nodD2 gene into the broad-host-range vector pMP92.

The strategy used to generate the different mutant strains described in Table 1 is shown in Fig. 1. Plasmid pK18mob, which is a suicide plasmid in rhizobia, was used for the homogenotization of the mutated versions of the ttsI nod box and the ttsI, nodD2 and nopA genes in S. fredii HH103 Rif $^{\mathrm{R}}$.

RT-PCR analysis. S. fredii strains HH103 Rif ${ }^{\mathrm{R}}$, SVQ533 and SVQ318 were incubated with shaking at $28{ }^{\circ} \mathrm{C}$ in YM medium supplemented with genistein $(3.7 \mu \mathrm{M})$ when necessary. When the cultures reached an $\mathrm{OD}_{660}$ of 0.5 , cells were harvested and RNA was extracted using the RNAeasy mini kit (Qiagen) following the manufacturer's instructions. Retrotranscription of the RNA was carried out using the Quantitect kit (Qiagen). Primers used for amplification were: $\operatorname{rhcQintF}\left(5^{\prime}\right.$ CGGATGCCGATCTCGATGACA) and rhcQintR (5'-CCAACCTTCCACGGAGTCTGA); nopAintF (5'-TGTCACGAGTGCAGTTGGA) and nopAintR (5'-TGTCTGGAGCTCGGTCGTAA); HH16SF (5'-GGATCGGAGACAGGTGCTGCA) and HH16S-R (5'-CGTGTGTAGCCCAGCCCGTA).

Purification and analysis of secreted proteins. Extracellular proteins from S. fredii strains were recovered from $50 \mathrm{ml}$ of YM bacterial cultures grown on an orbital shaker (180 r.p.m.) for $40 \mathrm{~h}$ $\left(\sim 10^{9}\right.$ bacteria $\left.\mathrm{ml}^{-1}\right)$. Cultures were centrifuged for $20 \mathrm{~min}$ at $10000 \mathrm{~g}$ at $4{ }^{\circ} \mathrm{C}$. The supernatants were mixed with three volumes of cold acetone and maintained at $-20{ }^{\circ} \mathrm{C}$ for $24 \mathrm{~h}$. The mixtures were centrifuged for $45 \mathrm{~min}$ at $22000 \mathrm{~g}$ at $4{ }^{\circ} \mathrm{C}$. Dried pellets were resuspended in $300 \mu \mathrm{l}$ sample buffer [62.5 mM Tris/ $\mathrm{HCl}, \mathrm{pH} 6.8,2 \%$ $(\mathrm{w} / \mathrm{v})$ SDS, $10 \%(\mathrm{w} / \mathrm{v})$ glycerol, $5 \%(\mathrm{w} / \mathrm{v}) \beta$-mercaptoethanol and $0.001 \%(\mathrm{w} / \mathrm{v})$ Bromophenol Blue]. Extracellular proteins were separated by SDS-PAGE using the discontinuous buffer system of Laemmli (1970). Electrophoresis was performed on $15 \%$ (w/v) SDSpolyacrylamide gels and proteins were visualized by silver staining. 
Table 1. Bacterial strains and plasmids

Resistance phenotypes: $\operatorname{Str}^{\mathrm{R}}, \mathrm{Rif}^{\mathrm{R}}, \mathrm{Gm}^{\mathrm{R}}, \mathrm{Km}^{\mathrm{R}}, \mathrm{Nx}^{\mathrm{R}}, \mathrm{Ap}^{\mathrm{R}}$ and $\mathrm{Spc} \mathrm{R}^{\mathrm{R}}$, streptomycin, rifampicin, gentamicin, kanamycin, nalidixic acid, ampicillin and spectinomycin, respectively.

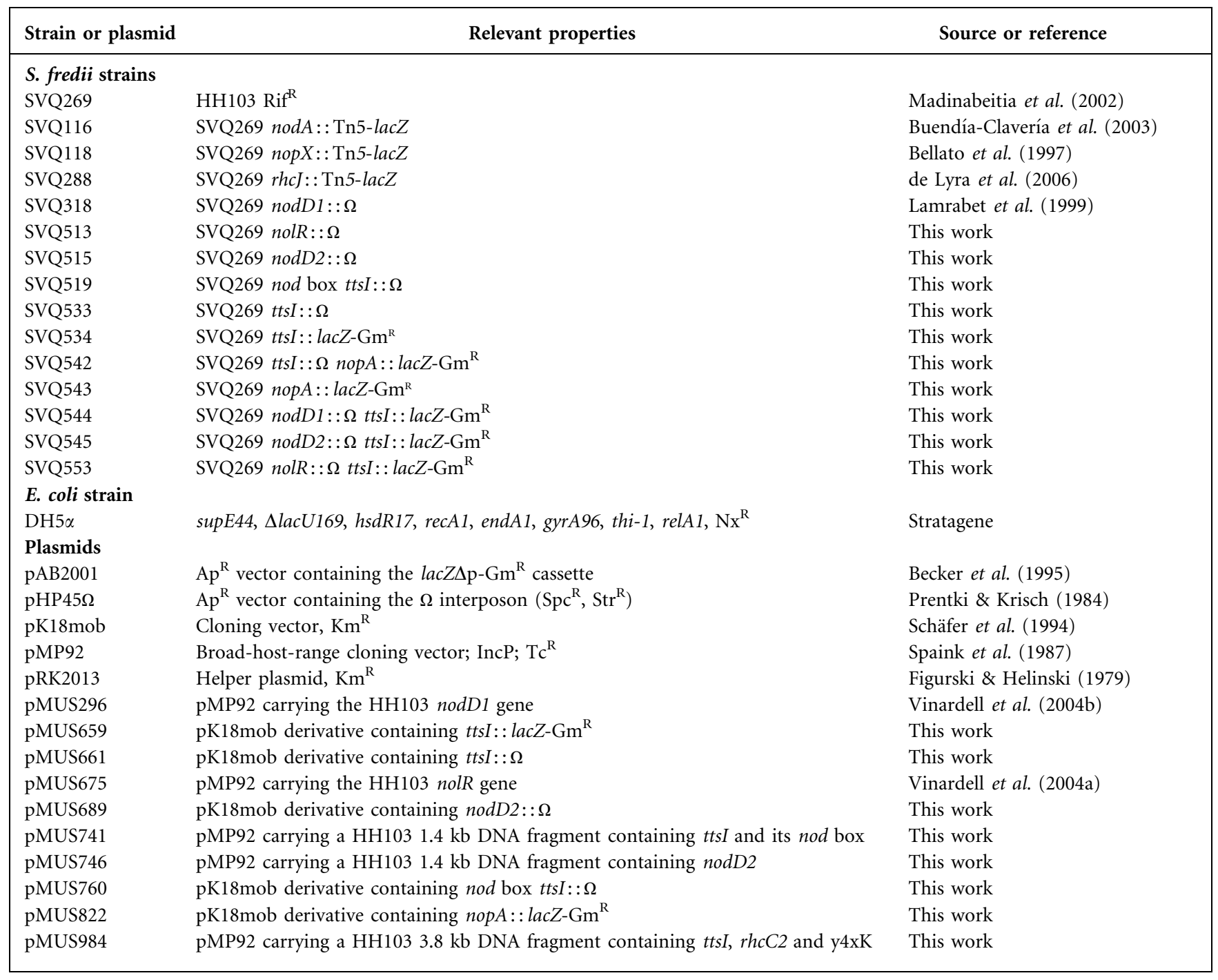

For immunostaining, extracellular proteins were separated on $15 \%$ $(\mathrm{w} / \mathrm{v})$ SDS-polyacrylamide gels and electroblotted to Immun-Blot PVDF membranes (Bio-Rad) using a Mini Trans-Blot electrophoretic transfer cell (Bio-Rad). Membranes were blocked with Tris-buffered saline (Sambrook et al., 1989) containing 2\%(w/v) BSA and then incubated with antibodies raised against NopA (Bartsev et al., 2003; Deakin et al., 2005) diluted 1:3000 in the same solution. Anti-rabbit immunoglobulin antibodies (alkaline phosphatase conjugate) were used as secondary antibodies. Reaction results were visualized using nitro-blue tetrazolium chloride-5-bromo-4-chloro- 3 '-indolyphosphate $p$-toluidine salt (NBT-BCIP) [45 $\mu \mathrm{l}$ NBT solution (75 mg $\mathrm{ml}^{-1}$ in $70 \%, \mathrm{v} / \mathrm{v}, N, N$-dimethylformamide) and $35 \mu \mathrm{l}$ BCIP solution (50 mg ml $\mathrm{ml}^{-1}$ in $N, N$-dimethylformamide) were added to $10 \mathrm{ml}$ developing buffer (80 mM Tris- $\mathrm{HCl}, \mathrm{pH} 9.5,100 \mathrm{mM} \mathrm{NaCl}, 50 \mathrm{mM}$ $\left.\left.\mathrm{MgCl}_{2}\right)\right]$.

Plant assays. Nodulation assays on Glycine max (L.) Merrill cvs Williams, Peking, Heinong 33, Kochi and Tribune, and on Erythrina variegata (L.) were performed as described by de Lyra et al. (2006). Each Leonard jar contained two plants (one plant in the case of $E$. variegata). For Glycyrrhiza uralensis, nodulation assays were carried out in mini-Leonard jars $(\sim 200 \mathrm{ml}$ for the upper part containing vermiculite and $\sim 170 \mathrm{ml}$ for the reservoir containing the plant nutritive solution) according to Vinardell et al. (2004a). Each plant was inoculated with $\sim 5 \times 10^{8}$ bacteria. Plants were grown for 42 days (90 days in the case of E. variegata) with a 16 h photoperiod at $25{ }^{\circ} \mathrm{C}$ in the light and $18{ }^{\circ} \mathrm{C}$ in the dark. Plant tops were dried at $70{ }^{\circ} \mathrm{C}$ for $48 \mathrm{~h}$ and weighed.

\section{RESULTS}

\section{Isolation of the S. fredii HH103 ttsI gene}

In order to isolate the $S$. fredii HH103 ttsI gene, primers y4xiF and y4xiR were designed from the coding sequence of the ttsI gene of Rhizobium sp. NGR234 (GenBank accession no. AE000106). With these primers and using $S$. fredii HH103 genomic DNA as template, a 1405 bp PCR 

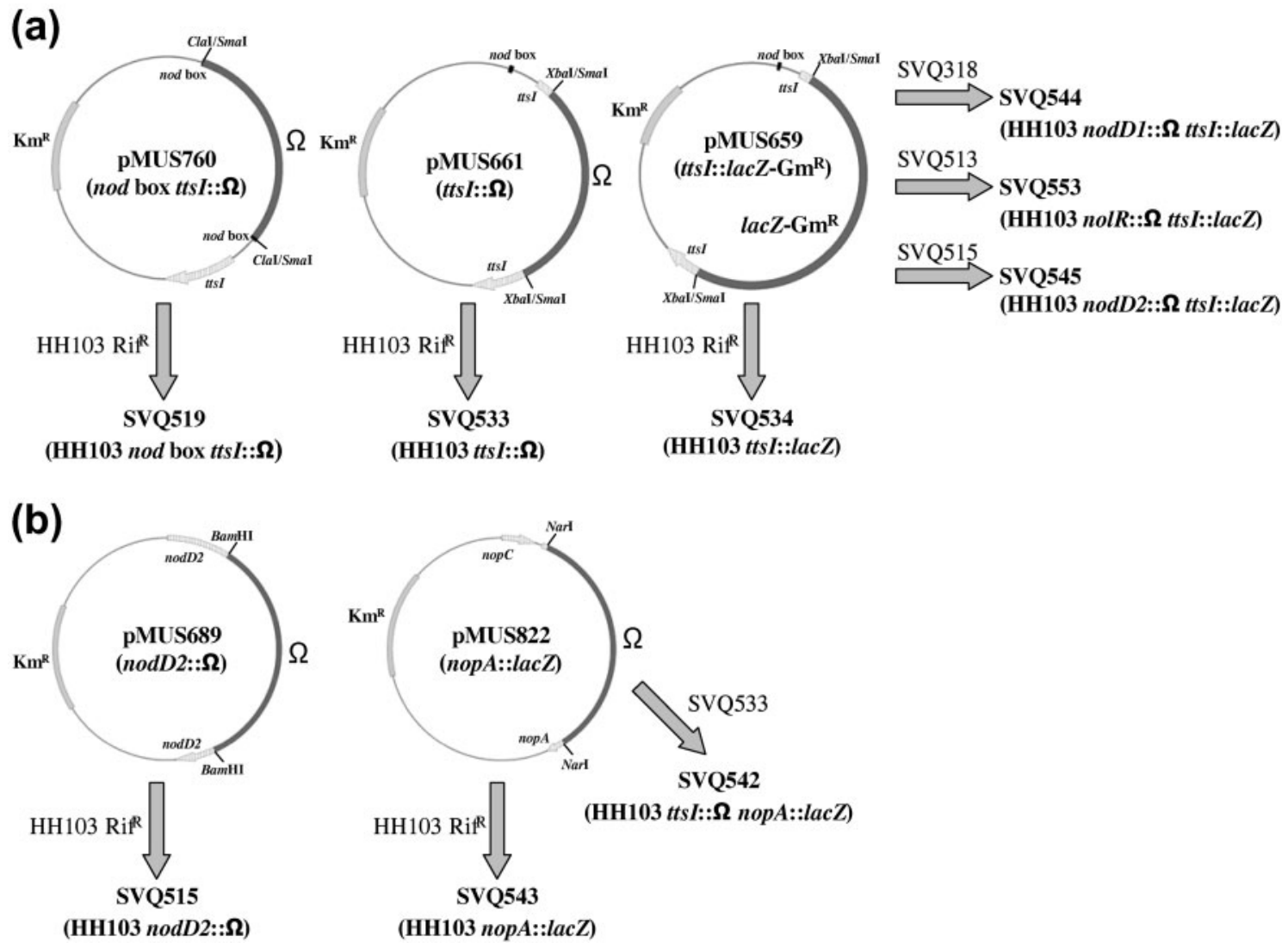

Fig. 1. (a) Derivatives of plasmid pK18mob carrying the $\Omega$ interposon to the $S$. fredii $\mathrm{HH} 103 \mathrm{Rif}^{\mathrm{R}}$ tts/ nod box (pMUS760), and the $t t s /$ coding sequence interrupted by the $\Omega$ interposon (pMUS661) or by the lacZ-Gm ${ }^{R}$ cassette (pMUS659). Plasmids were individually transferred to $\mathrm{HH} 103 \mathrm{Rif}^{\mathrm{R}}$. Transconjugants were selected in which the wild-type sequences had been substituted with their mutated versions by double recombination. In addition, the tts/:: lacZ-Gm ${ }^{R}$ mutation was homogenotized in strains SVQ318 $\left(\mathrm{HH} 103 \mathrm{Rif}^{\mathrm{R}}\right.$ nodD1:: $\left.\Omega\right)$, SVQ513 $\left(\mathrm{HH} 103 \mathrm{Rif}^{\mathrm{R}}\right.$ nolR:: $\left.\Omega\right)$ and SVO515 $\left(\mathrm{HH} 103 \mathrm{Rif}^{\mathrm{R}}\right.$ nodD2:: $\left.\Omega\right)$ in order to obtain double mutants. (b) Derivatives of plasmid pK18mob carrying the $\Omega$ interposon to the nodD2 (pMUS689) and nopA (pMUS822) genes. Both in vitro-mutated genes were homogenotized in the wild-type strain HH103 Rif ${ }^{\mathrm{R}}$. The nopA:: lacZ-Gm ${ }^{\mathrm{R}}$ mutation was also homogenotized in strain SV0533 $\left(\mathrm{HH} 103 \mathrm{Rif}^{\mathrm{R}} \mathrm{tts} /:: \Omega\right)$ to generate a $t$ sl, nopA double mutant. Restriction endonucleases used for in vitro mutagenesis are indicated. Homogenotizations were confirmed by hybridization in all cases.

fragment was amplified. This fragment was sequenced (AY184383) and cloned into the broad-host-range vector pMP92, generating plasmid pMUS741.

The 1405 bp sequenced fragment contains one complete ORF, the ttsI gene, which extends between positions 589 and 1269 and shows 100, 99, 79 and $69 \%$ identity to the ttsI genes of S. fredii USDA257 (AF229441), Rhizobium sp. NGR234 (U00090), M. loti MAFF303099 (BA000012) and B. japonicum USDA110 (AF322012), respectively. The deduced protein sequence of the $S$. fredii $\mathrm{HH} 103$ ttsI gene (226 aa, AAO25539) was 100, 99, 80 and $67 \%$ identical to those of strains S. fredii USDA257 (226 aa, AAL98682), Rhizobium sp. NGR234 (226 aa, AAB91932), M. loti MAFF303099 (223 aa, BAB52643) and B. japonicum USDA110 (229 aa, BAC47108).

The nod box located upstream of the Rhizobium sp. NGR234 ttsI gene was also present in S. fredii HH103 (positions 251-295), with only one mismatch (position 254: $\mathrm{T}$ instead of $\mathrm{C}$ ). Interestingly, a well-conserved NolR-binding site (TTTAGGATTGGGTAAT), extending between positions 83 and 98 (Vinardell et al., 2004a), was also found upstream of the nod box.

As described in Methods, three ttsI mutants were generated. Mutants SVQ533 and SVQ534 harbour the $\Omega$ interposon and the lacZ-Gm ${ }^{\mathrm{R}}$ cassette, respectively, in the ttsI coding sequence. Strain SVQ519 harbours the $\Omega$ interposon in the nod box upstream of ttsI. These mutants showed no alteration in LCO, LPS and plasmid profiles when compared with the parental strain HH103 Rif ${ }^{\mathrm{R}}$ (data not shown).

\section{Regulation of $t$ tsl by NodD1, NodD2 and NolR}

As previously mentioned, type III secretion of proteins is a flavonoid-dependent process that requires the presence of NodD (Krause et al., 2002; Marie et al., 2004). The role of 
other regulatory genes, such as nodD2 and nolR, in Nops secretion has also been investigated (Krishnan et al., 1995; Marie et al., 2003; Vinardell et al., 2004a).

To elucidate the effects of the $S$. fredii HH103 NodD1, NodD2 and NolR proteins on Nops secretion, we first individually analysed their effect on the transcriptional regulation of ttsI. For this purpose, the $t t s I:$ : lacZ-Gm ${ }^{\mathrm{R}}$ mutation was homogenotized into nodD1, nodD2 and nolR mutant backgrounds. Thus, three double mutants were obtained: SVQ544 (HH103 Rif ${ }^{\mathrm{R}}$ nodD1:: $\Omega$ ttsI: : lacZ-Gm ${ }^{\mathrm{R}}$ ), SVQ553 (HH103 Rif $^{\mathrm{R}}$ nolR:: $\Omega$ ttsI::lacZ-Gm${ }^{\mathrm{R}}$ ), and SVQ545 (HH103

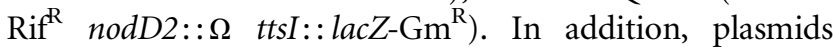
pMUS296, pMUS746 and pMUS675, which harbour the nodD1, nodD2, and nolR genes, respectively, subcloned into plasmid pMP92, were transferred by conjugation to strain SVQ534 (HH103 Rif ${ }^{\mathrm{R}}$ ttsI : : lacZ-Gm $\left.{ }^{\mathrm{R}}\right)$.

The results are summarized in Table 2. As expected, the activity of $t t s I$ in the absence of NodD1 could only reach basal levels when induced with genistein, confirming that the expression of ttsI depends on NodD1. The presence of multiple copies of nodD1 significantly increased the expression of the ttsI::lacZ-Gm ${ }^{\mathrm{R}}$ fusion when compared with the control without plasmid. In marked contrast, expression of ttsI in the presence of genistein and multiple copies of nolR showed a statistically significant decrease, whereas the inactivation of the nolR gene caused a twofold increase in the expression of ttsI. Although NodD2 has been described as being necessary for Nops secretion in other rhizobial strains, the inactivation or overexpression of the nodD2 gene did not exert a clear effect on the transcription of $t t s I$.

\section{Regulation of $\boldsymbol{t t s}$ by flavonoids and $\mathrm{pH}$}

A comparative study of the effect of 20 different flavonoids on the activities of $t t s I$ and $\operatorname{nodA}$, involved in the

Table 2. $\beta$-Galactosidase activity (Miller units) of the ttsl: : lacZ-Gm ${ }^{\mathrm{R}}$ fusion of $S$. fredii $\mathrm{HH} 103$ in the presence of extra copies of nodD1 (pMUS296), nodD2 (pMUS746) and nolR (pMUS675), and activity in $\operatorname{nodD1}$, nodD2 and nolR mutant backgrounds

Data are the mean $\pm \mathrm{SD}$ of at least two independent experiments performed in triplicate.

\begin{tabular}{|lcc|}
\hline Strain & $\begin{array}{c}\text { Without genis- } \\
\text { tein }\end{array}$ & $\begin{array}{c}\text { With genis- } \\
\text { tein }^{*}\end{array}$ \\
\hline ttsI:: lacZ & $62 \pm 6$ & $232 \pm 30$ \\
ttsI: : lacZ (pMUS296) & $71 \pm 3$ & $491 \pm 53$ \\
ttsI: : lacZ (pMUS746) & $88 \pm 4$ & $272 \pm 13$ \\
ttsI:: lacZ (pMUS675) & $70 \pm 2$ & $132 \pm 3$ \\
nodD1:: $\Omega$ ttsI:: lacZ & $43 \pm 1$ & $46 \pm 3$ \\
nodD2:: $\Omega$ ttsI:: lacZ & $42 \pm 1$ & $224 \pm 9$ \\
nolR:: $\Omega$ ttsI:: lacZ & $75 \pm 4$ & $473 \pm 24$ \\
\hline
\end{tabular}

${ }^{\star}$ Genistein concentration was $3.7 \mu \mathrm{M}$. biosynthesis of Nod factors, was carried out. The results, shown in Table 3, indicate that the best flavonoid inducers for ttsI were coumestrol, genistein and daidzein (all released by roots of soybeans McCall and Peking; Pueppke et al., 1998), apigenin and morin. Coumestrol was the most potent inducer among these five flavonoids. Curiously, 7-hydroxyflavone, naringenin, hesperetin and isoliquiritigenin, which induce the expression of $\operatorname{nodA}$ at least sixfold in comparison with the control without flavonoids, could only induce the expression of ttsI less than twofold. Other good inducer flavonoids for nodA, such as 7,4'-dihydroxyflavone, quercetin, fisetin and chrysin, only induced the expression of ttsI twofold.

Environmental acidity is a host-associated signal of importance in host detection. The soil adjacent to plant roots is generally acidic, with $\mathrm{pH}$ values between 5 and 6.5 (Marschner, 1995). As expression of T3SS genes occurs in the early stages of the infection process (Perret et al., 1999), the environmental $\mathrm{pH}$ could be a factor affecting the activity of these genes. To elucidate how the $\mathrm{pH}$ could affect the expression of $t$ tsI and nodA, $\beta$-galactosidase assays were carried out, adjusting the $\mathrm{pH}$ of the $\mathrm{YM}$ medium to the range 6-8. Results obtained indicated that the expression of both $t t s I$ and $\operatorname{nodA}$, when induced with genistein, showed its maximum value at $\mathrm{pH} 6$ and then decreased progressively to $\mathrm{pH} 8$ (Table 4).

\section{ttsl is the transcriptional regulator of T3SS genes in $\mathrm{S}$. fredii $\mathrm{HH} 103$}

To study the transcriptional regulation of the $S$. fredii HH103 tts region, plasmid pMUS741, which harbours the $S$. fredii HH103 ttsI gene and its nod box cloned into broad-host-range plasmid pMP92, was transferred to two S. fredii HH103 mutant strains carrying a Tn5-lacZ insertion into nopX and $r h c J$, and also to a nopA::lacZ$\mathrm{Gm}^{\mathrm{R}}$ mutant derivative. Analysis of the promoter sequences of these genes showed that they are preceded by a tts box, the putative promoter sequence located upstream of genes controlled by ttsI (TTGTCAGCTTTTCGAAAGCTGGAGCTCATA, $43 \mathrm{bp}$ upstream of nopCA; TAGTCAGCGTGTCGTCAGCTCGCCTCGCTA, $40 \mathrm{bp}$ upstream of nopBrhcJUV; TCGTCAGTTTCTCGAAAGCTAAACCGCTCA, 189 bp upstream of nopX).

As shown in Table 5, overexpression of ttsI significantly increased the activity of all genes tested upon induction with genistein. Interestingly, their activity was also enhanced in the presence of extra copies of $t t s I$ in the absence of an inducer, almost reaching the values obtained when induced with genistein.

To confirm the results obtained by the addition of extra copies of $t t s I$, a double mutant $t t s I:: \Omega$ nopA : : lacZ-Gm ${ }^{\mathrm{R}}$ was constructed. As shown in Table 5, addition of genistein strongly induced the transcription of nopA, but this activation dropped to basal levels in the ttsI mutant background, suggesting that expression of nopA is strictly TtsI-dependent. 
Table 3. Responsiveness of the $t t s /$ and nodA genes to different flavonoids

Data (expressed as Miller units) are the mean of at least two independent experiments performed in triplicate. $n$, Fold induction with respect to the control without flavonoids.

\begin{tabular}{|c|c|c|c|c|c|c|}
\hline \multirow[t]{2}{*}{ Flavonoid } & \multirow[t]{2}{*}{ Concentration $(\mu \mathrm{M})$} & \multirow[t]{2}{*}{ Hydroxylation pattern } & \multicolumn{2}{|c|}{ ttsI: : lacZ } & \multicolumn{2}{|c|}{$\operatorname{nod} A:: \operatorname{lac} Z$} \\
\hline & & & Mean \pm SD & $n$ & $\operatorname{Mean} \pm$ SD & $n$ \\
\hline None & & & $57.8 \pm 10$ & 1 & $68.5 \pm 3$ & 1 \\
\hline \multicolumn{7}{|l|}{ Flavones } \\
\hline Flavone & 4.5 & & $46.7 \pm 1.15$ & 0.8 & $70.73 \pm 5.9$ & 1 \\
\hline 5-Hydroxyflavone & 4.2 & 5 & $65.3 \pm 3.2$ & 1.1 & $75.97 \pm 2.2$ & 1.1 \\
\hline 7-Hydroxyflavone & 4.2 & 7 & $94 \pm 13$ & 1.6 & $439.1 \pm 12.2$ & 6.4 \\
\hline 7,4'-Dihydroxyflavone & 3.9 & $7,4^{\prime}$ & $121.7 \pm 19.4$ & 2.1 & $520 \pm 19.6$ & 7.6 \\
\hline Chrysin & 3.9 & 5,7 & $149.3 \pm 9.3$ & 2.6 & $462.3 \pm 5.7$ & 6.7 \\
\hline Apigenin & 3.7 & $4^{\prime}, 5,7$ & $208.7 \pm 15.3$ & 3.6 & $561.3 \pm 14.2$ & 8.2 \\
\hline Luteolin & 3.5 & $3^{\prime}, 4^{\prime}, 5,7$ & $127.3 \pm 2.3$ & 2.2 & $359.7 \pm 8.1$ & 5.2 \\
\hline \multicolumn{7}{|l|}{ Flavonols } \\
\hline Kaempferol & 3.5 & $4^{\prime}, 3,5,7$ & $163.3 \pm 4.5$ & 2.8 & $472 \pm 7.8$ & 6.9 \\
\hline Quercetin & 3.0 & $3^{\prime}, 4^{\prime}, 3,5,7$ & $122.7 \pm 10.3$ & 2.1 & $426 \pm 28.8$ & 6.2 \\
\hline Fisetin & 3.5 & $3^{\prime}, 4^{\prime}, 3,7$ & $130.3 \pm 13.6$ & 2.2 & $437.7 \pm 26.6$ & 6.4 \\
\hline Morin & 3.3 & $2^{\prime}, 4^{\prime}, 3,5,7$ & $216.7 \pm 12.6$ & 3.7 & $456.8 \pm 53.3$ & 6.7 \\
\hline \multicolumn{7}{|l|}{ Flavanones } \\
\hline Flavanone & 4.5 & & $57.3 \pm 2.5$ & 1 & $74.7 \pm 3.8$ & 1.1 \\
\hline 6-Hydroxyflavanone & 4.2 & 6 & $54.3 \pm 2.5$ & 0.9 & $70.5 \pm 9.1$ & 1 \\
\hline Naringenin & 3.7 & $4^{\prime}, 5,7$ & $99 \pm 9.8$ & 1.7 & $446.7 \pm 15.2$ & 6.5 \\
\hline Hesperetin & 3.3 & $3^{\prime}, 4^{\prime}-\mathrm{CH}_{3}, 5,7$ & $98.3 \pm 5.8$ & 1.7 & $467.2 \pm 14.8$ & 6.8 \\
\hline \multicolumn{7}{|l|}{ Isoflavones } \\
\hline Daidzein & 3.9 & $7,4^{\prime}$ & $214.3 \pm 7.1$ & 3.7 & $472 \pm 17.6$ & 6.9 \\
\hline Genistein & 3.7 & $5,7,4$ & $220.7 \pm 11.6$ & 3.8 & $462 \pm 34.0$ & 6.7 \\
\hline \multicolumn{7}{|l|}{ Others } \\
\hline Coumestrol & 3.9 & 7,12 & $252.9 \pm 30.6$ & 4.4 & $359 \pm 9.85$ & 5.2 \\
\hline Isoliquiritigenin & 3.7 & $4,2^{\prime}, 4^{\prime}$ & $105.7 \pm 10.3$ & 1.8 & $561 \pm 5.9$ & 8.2 \\
\hline Umbelliferone & 6.2 & 7 & $77.8 \pm 2.7$ & 1.3 & $83.7 \pm 18$ & 1.2 \\
\hline
\end{tabular}

Semiquantitative RT-PCR assays were also carried out to study the expression of the nopA and rhcQ genes in ttsI and nodD1 mutant backgrounds and in the absence or presence of genistein. An internal fragment of the HH103 16S rDNA was used as a control. As shown in Fig. 2, inactivation of nodD1 or $t$ tsI led to a basal level of transcription of the $r h c Q$ and nopA genes. However, addition of genistein to the growth media clearly enhanced both nopA and $r h c Q$ transcript levels.

Table 4. Effect of $\mathrm{pH}$ on the $\beta$-galactosidase activity (Miller units) of the tts /: : lacZ and nod $A$ : : lac $Z$ fusions

Data are the mean $\pm \mathrm{SD}$ of at least two independent experiments performed in triplicate.

\begin{tabular}{|lccc|}
\hline Strain & pH $\mathbf{6 . 0}$ & pH 7.0 & pH 8.0 \\
\hline ttsI: : lacZ & $58 \pm 5$ & $69 \pm 4$ & $70 \pm 6$ \\
ttsI: lacZ+ genistein & $256 \pm 9$ & $216 \pm 5$ & $163 \pm 6$ \\
nodA:: lacZ & $123 \pm 18$ & $125 \pm 7$ & $145 \pm 14$ \\
nodA:: lacZ+genistein & $1294 \pm 121$ & $631 \pm 40$ & $424 \pm 34$ \\
\hline
\end{tabular}

${ }^{\star}$ Genistein concentration was $3.7 \mu \mathrm{M}$.

\section{Inactivation of tts/ abolishes Nops secretion}

The involvement of the S. fredii HH103 ttsI gene in Nops secretion was investigated. Rodrigues et al. (2007) have shown previously that $\mathrm{HH} 103$ secretes, in response to flavonoids, at least eight Nops with approximate molecular masses of $180 \mathrm{kDa}$ (NopD), $60 \mathrm{kDa}$ (NopX and NopM), 37 or $34 \mathrm{kDa}$ (NopL), $31 \mathrm{kDa}(\mathrm{NopP}), 21 \mathrm{kDa}$ (NopB), $12 \mathrm{kDa}(\mathrm{NopC})$ and $6 \mathrm{kDa}(\mathrm{NopA})$.

SDS-PAGE experiments showed that inactivation of ttsI or its nod box completely abolished secretion of Nops to the extracellular medium upon induction with flavonoids, indicating that the nod box preceding $t t s I$ is essential for Nops secretion (Fig. 3). Protein secretion could not be restored when a broad-host-range plasmid carrying tts (pMUS741) was transferred to any of the mutant strains (data not shown). However, transfer of plasmid pMUS984, a derivative of plasmid pMP92 that carries the $t$ tsI, rhcC2 and $y 4 x K$ genes, to SVQ533 restored its capacity to secrete Nops to the extracellular medium in response to flavonoids (Fig. 3).

As described previously, NodD1 and flavonoids are necessary for the transcriptional activation of $t t s I$, NolR 
Table 5. $\beta$-Galactosidase activity (Miller units) of different mutants that harbour lac $Z$ insertions in genes belonging to the tts region in the presence and absence of plasmid pMUS741

Data are the mean $\pm \mathrm{SD}$ of at least two independent experiments performed in triplicate.

\begin{tabular}{|c|c|c|}
\hline Strain & $\begin{array}{l}\text { Without } \\
\text { genistein }\end{array}$ & $\begin{array}{c}\text { With } \\
\text { genistein }{ }^{\star}\end{array}$ \\
\hline HH103-1 nopX: : lacZ & $113 \pm 26$ & $1240 \pm 48$ \\
\hline HH103-1 порX:: lacZ (pMUS741) & $1240 \pm 66$ & $1510 \pm 17$ \\
\hline HH103-1 rhcJ:: lacZ & $179 \pm 5$ & $1214 \pm 69$ \\
\hline HH103-1 rhcJ:: lacZ (pMUS741) & $1167 \pm 48$ & $1416 \pm 13$ \\
\hline HH103 Rif $^{\mathrm{R}}$ nopA: : lacZ & $326 \pm 31$ & $2146 \pm 46$ \\
\hline HH103 $\operatorname{Rif}^{\mathrm{R}}$ nopA:: lacZ (pMUS741) & $1617 \pm 63$ & $3022 \pm 29$ \\
\hline HH103 $\operatorname{Rif}^{\mathrm{R}} t t s I:: \Omega$ nopA $:: \operatorname{lac} Z$ & $361 \pm 25$ & $392 \pm 23$ \\
\hline
\end{tabular}

${ }^{\star}$ Genistein concentration was $3.7 \mu \mathrm{M}$.

functions as a repressor, and NodD2 is not involved in its transcriptional regulation. The role of NolR in Nops secretion has been studied previously (Vinardell et al., 2004a). In this work, the effect of the mutation of nodD1 or nodD2 on Nops secretion was analysed. As shown in Fig. 3, inactivation of nodD1 completely abolished Nops secretion, whereas the mutation of nodD2 had no effect on secretion of proteins to the extracellular medium upon induction with genistein. These results were confirmed by using specific antibodies raised against NopA. This protein was not detected in the supernatants of the ttsI or nodD1 mutant strains when induced with genistein (Fig. 3b).

Secretion of Nops did not become constitutive in the presence of multiple copies of $t$ tsI (Fig. $4 \mathrm{a}, \mathrm{b}$ ) or a DNA fragment that contained the $t t s I, r h c C 2$ and $\mathrm{y} 4 \mathrm{xK}$ genes (data not shown). However, the nopX, rhcJ and nopA genes were expressed in the presence of multiple copies of $t t s I$ but

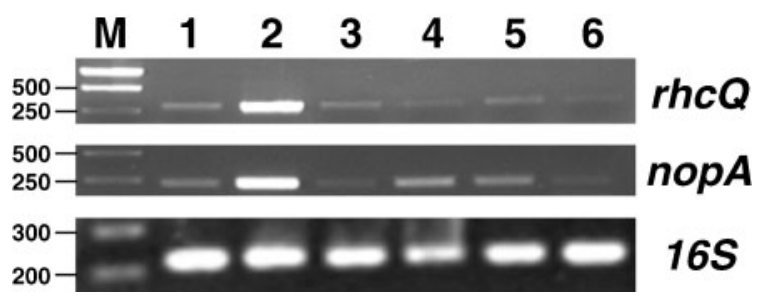

Fig. 2. Semiquantitative RT-PCR analysis of $S$. fredii $\mathrm{HH} 103$ mRNA. Total RNA isolated from $\mathrm{HH}_{103}$ grown in the absence (lanes 1, 3 and 5) or presence (lanes 2, 4 and 6) of genistein $(3.7 \mu \mathrm{M})$ was used as a template for RT-PCR. The products obtained using primers designed to amplify an internal fragment of the coding region of $r h c Q$ and nopA are shown. The 16S RNA gene was used as a control. Sizes of the molecular mass markers (M) are shown on the left. Lanes: 1 and 2, HH103 Rif ${ }^{\mathrm{R}}$; 3 and 4, $\mathrm{HH} 103 \mathrm{Rif}^{\mathrm{R}}$ ttsl $:: \Omega ; 5$ and $6, \mathrm{HH} 103 \mathrm{Rif}^{\mathrm{R}} \operatorname{nod} 1:: \Omega$. in the absence of flavonoids (Table 5). The absence of Nops secretion in the presence of flavonoids when multiple copies of the nolR gene were present (Vinardell et al., 2004a) was confirmed by using anti-NopA antiserum (Fig. 4b). In contrast to the results obtained by Krishnan et al. (1995), constitutive secretion of Nops could not be observed in the presence of extra copies of nodD2 (Fig. 4).

\section{The absence of Nops affects the symbiosis between S. fredii HH103 and its host legumes in a host-dependent manner}

To elucidate the role of Nops in the interaction between $S$. fredii HH103 and Glycine max, which forms determinate nodules, the symbiotic properties of the mutant strain SVQ519 (HH103 Rif $^{\mathrm{R}}$ nod box $t t s I:: \Omega$ ) were determined in plant infection tests with five different soybean cultivars:

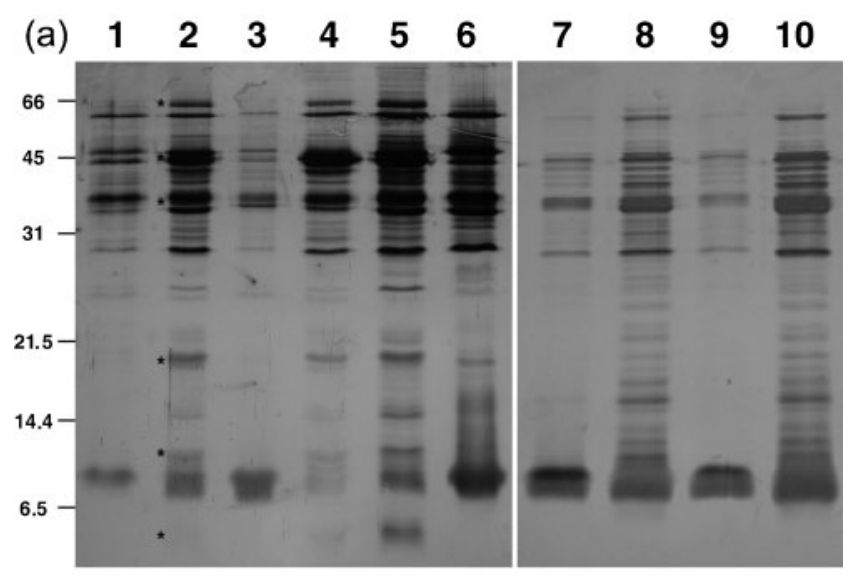

(b)

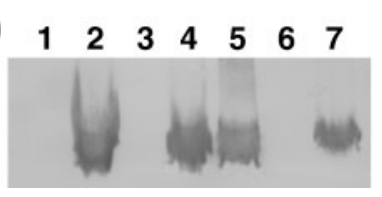

Fig. 3. Extracellular protein profiles of various $S$. fredii $\mathrm{HH}_{103}$ derivatives. (a) Silver-stained gel of secreted proteins of noninduced cultures of $\mathrm{HH} 103 \mathrm{Rif}^{\mathrm{R}}$ (lane 1), HH103 $\mathrm{Rif}^{\mathrm{R}}$ nod box tts/:: $\Omega$ (lane 7), HH103 Rif ${ }^{\mathrm{R}}$ tts/:: $\Omega$ (lane 9), and secreted proteins of induced cultures (genistein, $3.7 \mu \mathrm{M}$ ) of HH103 Rif $^{R}$ (lane 2), HH103 $\mathrm{Rif}^{\mathrm{R}}$ nodD1:: $\Omega$ (lane 3), HH103 Rif ${ }^{\mathrm{R}}$ nodD2 $:: \Omega$ (lane 4), $\mathrm{HH} 103 \mathrm{Rif}^{\mathrm{R}}$ nolR:: $\Omega$ (lane 5), HH103 Rif ${ }^{\mathrm{R}}$ ttsl:: $\Omega$ (pMUS984) (lane 6), HH103 Rif ${ }^{\mathrm{R}}$ nod box tts/:: $\Omega$ (lane 8) and $\mathrm{HH} 103 \mathrm{Rif}^{\mathrm{R}}$ ttsl:: $\Omega$ (lane 10). Proteins whose secretion depends on genistein are marked with an asterisk. Molecular masses (kDa) of the marker are shown on the left. (b) Immunodetection of NopA in extracellular-protein extracts of non-induced cultures of $S$. fredii $\mathrm{HH} 103 \mathrm{Rif}^{\mathrm{R}}$ (lane 1) and induced cultures (genistein, $3.7 \mu \mathrm{M}$ ) of HH103 Rif ${ }^{\mathrm{R}}$ (lane 2), HH103 Rif ${ }^{\mathrm{R}}$ nodD1:: $\Omega$ (lane 3), HH103 Rif ${ }^{\mathrm{R}}$ nodD2:: $\Omega$ (lane 4), HH103 Rif ${ }^{\mathrm{R}}$ nolR:: $\Omega$ (lane 5), HH103 Rif ${ }^{\mathrm{R}}$ ttsl:: $\Omega$ (lane 6), and HH103 Rif ${ }^{\mathrm{R}}$ tts/:: $\Omega$ (pMUS984) (lane 7). Samples were separated by $15 \%$ SDS-PAGE. 


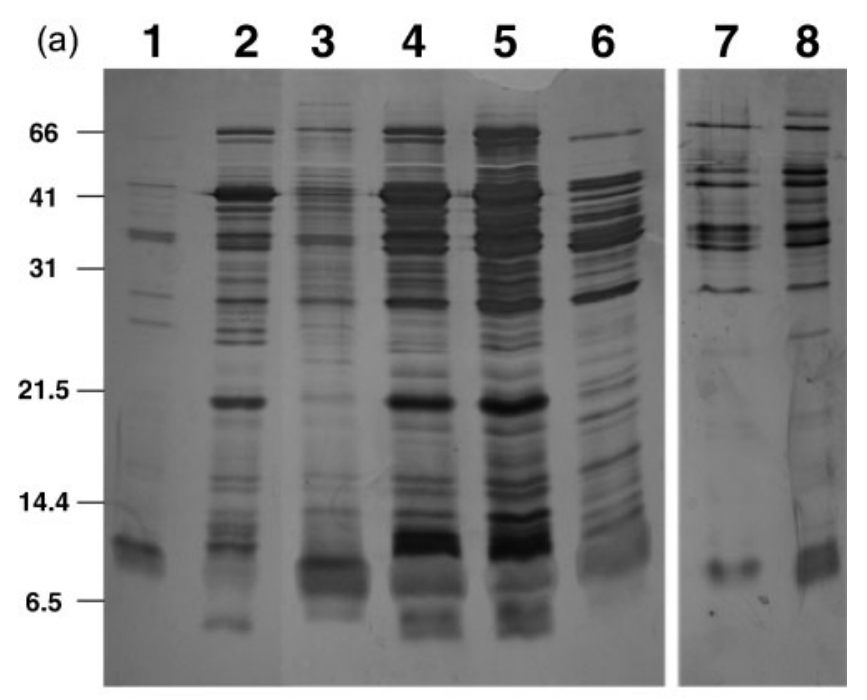

(b) $\quad \begin{array}{llllllll}1 & 2 & 3 & 4 & 5 & 6 & 7 & 8\end{array}$

Fig. 4. (a) Effect of the transfer of a plasmid carrying extra copies of tts / (pMUS741), nodD2 (pMUS746) or nolR (pMUS675) on the extracellular protein profiles of $S$. fredii $\mathrm{HH} 103$. Lanes: 1 and 2, $\mathrm{HH} 103 \mathrm{Rif}^{\mathrm{R}}$; 3 and 4, HH103 $\mathrm{Rif}^{\mathrm{R}}$ (pMUS741); 5 and 6, HH103 $\operatorname{Rif}^{R}$ (pMUS746); 7 and 8, HH103 Rif ${ }^{R}$ (pMUS675). Lanes 2, 4, 5 and 8: extracellular proteins obtained from cultures grown in the presence of genistein $(3.7 \mu \mathrm{M})$. Molecular masses $(k D a)$ of the marker are shown on the left. Samples were separated by $15 \%$ SDS-PAGE. (b) Immunodetection of NopA in the corresponding extracellular-protein extracts of the $S$. fredii $\mathrm{HH} 103$ derivatives shown in (a). Samples were separated by $15 \%$ SDS-PAGE.

Williams, Peking, Kochi, Tribune and Heinong 33, all of which are effectively nodulated by the wild-type strain $S$. fredii HH103. Effectors secreted by the T3SSs are usually recognized by specific plant receptors. Therefore, distinct soybean varieties could show differences in these receptors that would change their symbiotic behaviour with HH103. Two other hosts, E. variegata, a tropical legume that is poorly nodulated by HH103, and Glycyrrhiza uralensis, which forms indeterminate nodules, were also tested.

In Glycine max cultivars Williams and Peking, the number and fresh weight of nodules formed, as well as the planttop dry weight, were significantly lower $(\alpha=5 \%$, where $\alpha$ is the statistical significance of the differences observed using the Mann-Whitney non-parametric test) in plants inoculated with the mutant strain SVQ519 than in those inoculated with the parental strain HH103 Rif ${ }^{\mathrm{R}}$. In soybean cultivars Kochi and Heinong 33, only the number of nodules was significantly reduced $(\alpha=5$ and $10 \%$, respectively). No differences were detected between mutant SVQ519 and the parental strain HH103 Rif $^{\mathrm{R}}$ in 'Tribune' soybean (Table 6). Complementation of the mutant SVQ533 with plasmid pMUS984 restored its capacity to nodulate soybean Williams to that of the parental strain HH103 Rif $^{\mathrm{R}}$ (data not shown).

This symbiotic behaviour was also observed in Glycyrrhiza uralensis. Although the symbiotic performance of $S$. fredii $\mathrm{HH} 103 \mathrm{Rif}^{\mathrm{R}}$ on this plant was highly variable (nine plants nodulated of 10 inoculated, with a nodule number per plant that varied between 22 and 95), it was clearly superior to that of mutant SVQ519 (six plants nodulated of 10 inoculated, with the number of nodules per plant between two and 35). Despite this variability, which is reflected in the high SDs observed, all the parameters analysed were significantly lower $(\alpha=5 \%)$ in plants inoculated with SVQ519 than in those inoculated with the parental strain (Table 6).

In marked contrast, in E. variegata there was a significant increase $(\alpha=5 \%)$ in nodule number, fresh weight and plant-top dry weight when plants were inoculated with mutant SVQ519 in comparison with those inoculated with HH103 Rif $^{\mathrm{R}}$ (Table 6). These data suggest that Nops may be acting as a positive factor for a successful nodulation of S. fredii $\mathrm{HH} 103$ on some Glycine max cultivars and Glycyrrhiza uralensis, but could be interfering with nodulation in E. variegata.

Strains SVQ533 (HH103 Rif ${ }^{\mathrm{R}}$ ttsI:: $\Omega$ ) and SVQ534 $\left(\mathrm{HH} 103 \mathrm{Rif}^{\mathrm{R}}\right.$ ttsI::lacZ-Gm ${ }^{\mathrm{R}}$ ) exhibited the same symbiotic phenotype shown by SV519 in Glycine max, E. variegata and Glycyrrhiza uralensis plants (data not shown).

\section{DISCUSSION}

Rhizobial genes involved in type III secretion are grouped in the $t t s$ region, and secretion of nodulation outer proteins requires the presence of flavonoids and NodD. However, only one gene of the $t t s$ region, the ttsI gene, is preceded by a nod box (Marie et al., 2003; Viprey et al., 1998). TtsI has been proposed to be an intermediary in the regulatory cascade between NodD1 and T3SS-related genes, and seems to regulate the expression of the $t t s$ genes by binding to specific promoter sequences called tts boxes (Krause et al., 2002; Viprey et al., 1998). We have shown that the $S$. fredii HH103 ttsI gene is also activated by NodD1 and flavonoids (Table 2). As expected, inactivation of nodD1 completely abolished Nops secretion (Fig. 3). In contrast, the absence of the repressor protein NolR enhanced the expression of ttsI (Table 2) but did not cause an apparent change in the profiles of secreted proteins upon induction with genistein (Vinardell et al., 2004a; Fig. 3). However, the presence of multiple copies of nolR clearly reduced the activity of $t t s I$ (Table 2) and repressed secretion of Nops (Vinardell et al., 2004a; Fig. 4). In S. meliloti, NolR repressed both nodD1 and nodD2, causing a general decrease in nod gene expression (Cren et al., 1995). In $S$. fredii $\mathrm{HH} 103$ the presence of multiple copies of nolR repressed the transcription not only of nod genes but also of several tts genes, including nopX and rhcJ (Vinardell et al., 2004a). In this strain, the nodD1 and ttsI coding 
Table 6. Plant responses to inoculation of Glycine max, E. variegata and Glycyrrhiza uralensis with $\mathrm{S}$. fredii $\mathrm{HH} 103 \mathrm{Rif}{ }^{\mathrm{R}}$ and SVO519 (=HH103 Rif ${ }^{\mathrm{R}}$ nod box ttsl:: $\Omega$ )

Data represent mean \pm SD of six jars for each soybean cultivar. Each jar contained two soybean plants. Determinations were made 6 weeks after inoculation for soybean. For E. variegata plants, data represent mean \pm sD of five plants. Determinations were made 90 days after inoculation. For Glycyrrhiza uralensis, data represent mean \pm SD values obtained with nodulated plants. Determinations were made 6 weeks after inoculation. For each legume tested, bacteria isolated from 20 nodules formed by each inoculant showed the expected resistance markers. Mutant SVQ519 was individually compared with its parental strain HH103 Rif $^{\mathrm{R}}$ by using the Mann-Whitney non-parametric test.

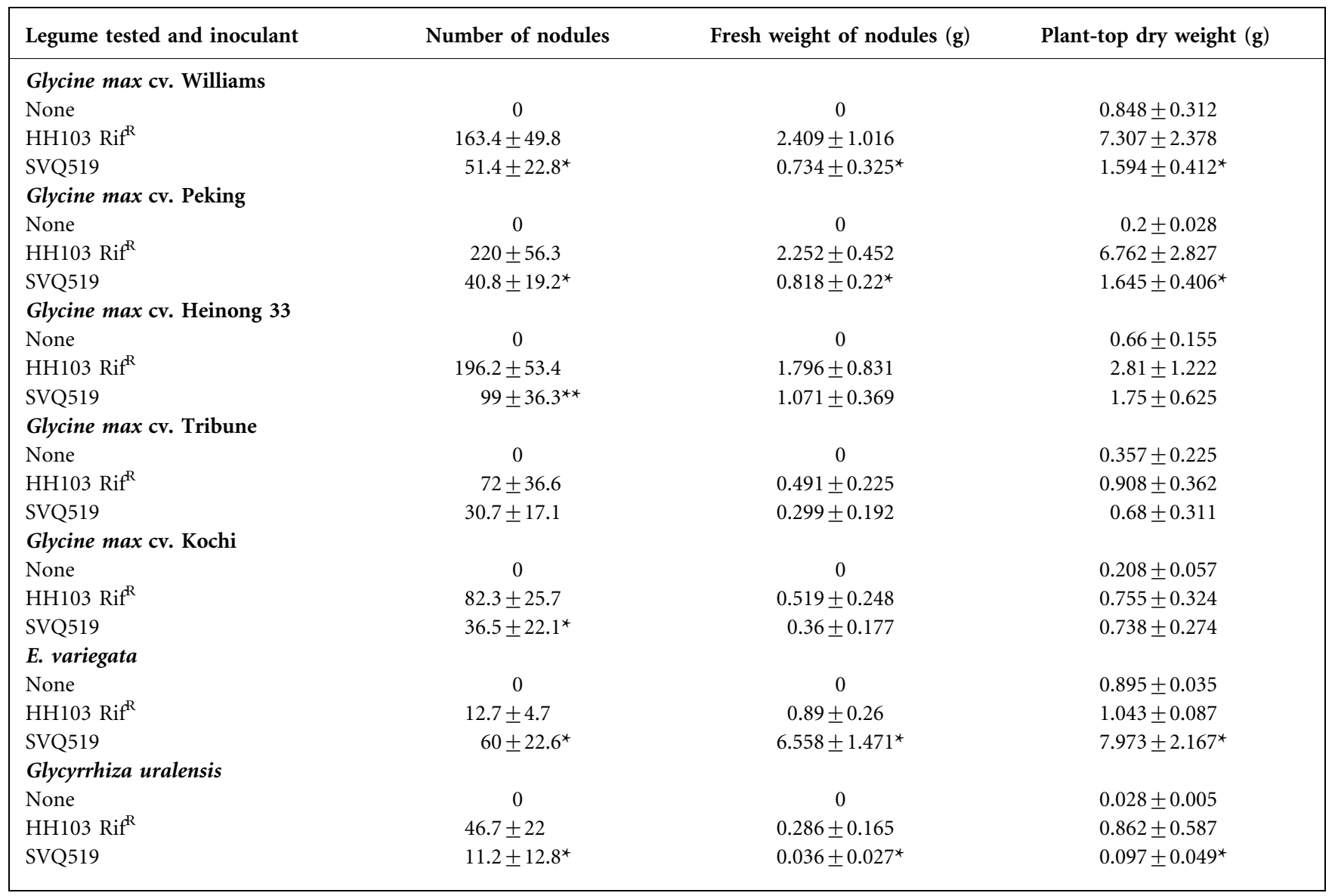

${ }^{\star}$ Numbers in the same column significantly different at the $\alpha=5 \%$ level.

${ }^{*}$ Numbers in the same column significantly different at the $\alpha=10 \%$ level.

regions are preceded by a NolR-binding site. Therefore, the negative effect of NolR on the activity of $t t s I$ and in Nops secretion could be explained by a repression of nodD1, which is necessary for the transcription of $t t s I$, by a repression of ttsI mediated by direct binding of NolR to the NolR-binding site upstream of ttsI, or by both mechanisms.

The presence of multiple copies of the nodD2 gene in $S$. fredii USDA257 makes Nops secretion constitutive (Bellato et al., 1997; Krishnan et al., 1995). However, in Rhizobium sp. NGR234 the presence of multiple copies of the nodD2 gene blocks Nops secretion (Marie et al., 2003). In contrast, in S. fredii HH103 no changes in the activity of ttsI or in Nops secretion were observed, either when the nodD2 gene was mutated or when it was overexpressed, suggesting that
nodD2 is not involved in the regulation of expression of ttsI in S. fredii HH103 (Table 2, Fig. 4).

Inactivation of the $S$. fredii $\mathrm{HH} 103$ ttsI gene completely abolished secretion of Nops to the extracellular medium (Fig. 3). Moreover, inactivation of the nod box preceding $t t s I$ gave the same protein profile as the ttsI mutant strain, confirming for the first time, to our knowledge, that this nod box is essential for the expression of the tts genes and secretion of nodulation outer proteins (Fig. 3). This is in agreement with the transcriptional regulation function assigned to TtsI. The S. fredii HH103 ttsI mutant was only complemented by a DNA fragment that, in addition to the $t t s I$ gene, carries the $r h c C 2$ and $\mathrm{y} 4 \mathrm{xK}$ genes (Fig. 3a, b). This result suggests that these genes constitute an operon. If this were the case, the mutation of the ttsI gene would have a 
polar effect on the transcription of downstream genes, which could be required for the biosynthesis of the secretion apparatus. The $r h c C 2$ gene encodes a secretin that is thought to be required for the biosynthesis of the type III secretion apparatus, while the amino acid sequence of $\mathrm{Y} 4 \mathrm{xK}$ indicates that it could be a lipoprotein (Marie et al., 2004; Viprey et al., 1998). To our knowledge, this is the first time that it has been possible to complement a mutation in a rhizobial $t t s I$ gene.

Despite the dependence of the expression of both $t t s I$ and nodA on NodD1, clear differences in the capacity of certain flavonoids to activate these genes were found (Table 3 ). The mechanism by which different flavonoids can differentially modulate the expression of the nod and $t t s$ genes is currently unknown. Although clear differences in flavonoid-mediated expression were found between ttsI and $\operatorname{nod} A$, the expression of both genes was much higher at acidic than at alkaline $\mathrm{pH}$ (Table 4). The fact that ttsI is responsive to differences in $\mathrm{pH}$ suggests that the $t t s I$ gene could be sensitive to environmental changes that may occur in the rhizosphere in the early steps of the symbiotic interaction.

The HH103 ttsI gene is responsible for the transcriptional activation of at least four genes of the tts region, nopX, $n o p A$, rhcJ and rhcQ (Table 5). Proteins NopX and NopA have been described as being associated with pilus-like surface appendages (Deakin et al., 2005; Krishnan et al., 2003), whereas RhcJ and RhcQ are components of the type III secretion machinery (Viprey et al., 1998). Nucleotide sequence analysis revealed the presence of a tts box-like element upstream of the coding region of these genes in HH103. Overexpression of ttsI and induction with genistein caused an increase in the activity of these genes when compared with the parental strain (Table 5). In addition, inactivation of ttsI completely blocked the expression of nopA and rhcQ (Table 5, Fig. 2). These results suggest that TtsI acts as a transcriptional activator of the $t t s$ genes and are in agreement with those reported by Krause et al. (2002) and Marie et al. (2004) that show that TtsI is responsible for the activation of nolU, nopP and $r h c V$ in B. japonicum USDA110 and of the nopB operon in Rhizobium sp. NGR234. Interestingly, addition of extra copies of ttsI induced the expression of nopX, rhcJ and nopA in the absence of flavonoids, making their expression constitutive (Table 5). However, ttsI was not constitutively expressed in the presence of extra copies of nodD1, although in this case the expression of the ttsI gene upon induction with genistein was double that obtained without extra copies of nodD1 (Table 2). It is also remarkable that the constitutive expression of the $t t s$ genes due to the presence of extra copies of ttsI (Table 5) did not result in constitutive Nops secretion (Fig. 4), suggesting that extra regulatory controls could prevent the translation of the constitutively expressed $t$ ts mRNAs.

The symbiotic role of nodulation outer proteins has been mainly investigated in Rhizobium sp. NGR234, S. fredii strains HH103 and USDA257, and B. japonicum USDA110. In Rhizobium sp. NGR234, tts mutants show different symbiotic phenotypes depending on the host plant (Viprey et al., 1998). Abolition of Nops secretion results in delayed nodulation of B. japonicum USDA110 on soybean Williams (Krause et al., 2002). In S. fredii, different strain-specific phenotypes have been observed. In strain USDA257, mutants in genes belonging to the nolXWBTUV locus gain the ability to induce nitrogen-fixing nodules on agronomically improved American soybean cultivars that are not naturally nodulated by the wild-type strain (Meinhardt et al., 1993). In contrast, in $\mathrm{HH} 103$, which naturally induces the formation of nitrogen-fixing nodules in both American and Asiatic soybeans, an rhcj mutant strain is impaired in its symbiotic capacity with soybean cultivars Williams and Peking. However, it shows an improved symbiotic behaviour with E. variegata (de Lyra et al., 2006).

The inactivation of the S. fredii HH103 ttsI gene provoked similar but more dramatic symbiotic effects on Williams soybean than the inactivation of the $r h c J$ gene (de Lyra et al., 2006). When compared with the parental strain, the reductions in nodule number and plant-top dry weight were, respectively, 68.5 and $78.2 \%$ for the ttsI mutant and 40.0 and $24.6 \%$ for the $r h c J$ derivative. Similar results were observed in Peking soybean. In symbiosis with E. variegata, the positive effect of the inactivation of $t t s I$ was stronger than that caused by the rhcJ mutation: increases of 372.4 versus $270.8 \%$ in nodule number and of 664.4 versus $348.2 \%$ in plant-top dry weight when compared with the parental strain.

Although it is difficult to compare results of different nodulation assays, the differences observed between the symbiotic capacities of the rhcJ and ttsI mutants could suggest a higher symbiotic relevance for the ttsI gene. The mutation of the rhcJ gene blocks the biosynthesis of the secretion machinery, but the lack of the transcriptional regulator TtsI could be able to affect not only the secretion of Nops but also the biosynthesis of other symbiotic signals in S. fredii $\mathrm{HH} 103$.

In Rhizobium sp. NGR234, ttsI activates the transcription of the rmlBDAwbg operon that is involved in the synthesis of rhamnose-rich polysaccharides (Marie et al., 2004). However, HH103 did not synthesize this polysaccharide. In fact, hybridization studies showed that the $r m l B$ gene was not present in the genome of this $S$. fredii strain (data not shown). The HH103 ttsI mutant showed the same LPS and LCO profiles as the parental strain, and its production of exopolysaccharide was also not affected (data not shown). However, we cannot discount the possibility that other important symbiotic signals, such as capsular polysaccharides, cyclic glucans or even molecules still unknown, could be controlled by ttsI.

In S. fredii $\mathrm{HH} 103$, the inactivation of the ttsI gene completely abolished Nops secretion, and the symbiotic effect of the mutation was host-dependent. Thus, the absence of Nops was detrimental to the symbiosis with all 
the Glycine max cultivars tested and with Glycyrrhiza uralensis, but beneficial in the case of the tropical legume $E$. variegata (Table 6). Glycine max and E. variegata plants form determinate nodules, whereas Glycine uralensis forms indeterminate nodules. Therefore, the beneficial or detrimental effect exerted by $S$. fredii $\mathrm{HH} 103$ Nops does not depend on the type of nodule formed by the host legume.

\section{ACKNOWLEDGEMENTS}

The authors would like to acknowledge the Spanish Ministerio de Ciencia y Tecnologiá (MCyT) (AGL2006-13758-C05-03) for funding the project. We also thank Dr W. J. Deakin (Département de Biologie Végétale, University of Geneva, Switzerland) for the generous gift of the NopA antibodies.

\section{REFERENCES}

Ausmees, N., Kobayashi, H., Deakin, W. J., Marie, C., Krishnan, H. B., Broughton, W. J. \& Perret, X. (2004). Characterization of NopP, a type III secreted effector of Rhizobium sp. strain NGR234. J Bacteriol 186, 4774-4780.

Bartsev, A. V., Boukli, N. M., Deakin, W. J., Staehelin, C. \& Broughton, W. J. (2003). Purification and phosphorylation of the effector protein NopL from Rhizobium sp. NGR234. FEBS Lett 554, 271-274.

Becker, A., Schmidt, M., Jäger, W. \& Pühler, A. (1995). New gentamicin resistance and lacZ promoter-probe cassettes suitable for insertion mutagenesis and generation of transcriptional fusions. Gene $162,37-39$.

Bellato, C., Krishnan, H. B., Cubo, T., Temprano, F. \& Pueppke, S. G. (1997). The soybean cultivar specificity gene nolX is present, expressed in a nodD-dependent manner, and of symbiotic significance in cultivar non-specific strains of Rhizobium (Sinorhizobium) fredii. Microbiology 143, 1381-1388.

Beringer, J. E. (1974). R factor transfer in Rhizobium leguminosarum. J Gen Microbiol 84, 188-198.

Broughton, W. J., Jabbouri, S. \& Perret, X. (2000). Keys to symbiotic harmony. J Bacteriol 182, 5641-5652.

Buendia-Claveria, A. M., Moussaid, A., Ollero, F. J., Vinardell, J. M., Torres, A., Moreno, J., Gil-Serrano, A. M., Rodríguez-Carvajal, M. A., Tejero-Mateo, P. \& other authors (2003). A purL mutant of Sinorhizobium fredii $\mathrm{HH} 103$ is symbiotically defective and altered in its lipopolysaccharide. Microbiology 149, 1807-1818.

Cren, M., Kondorosi, A. \& Kondorosi, E. (1995). NolR controls expression of the Rhizobium meliloti nodulation genes involved in the core Nod factor synthesis. Mol Microbiol 15, 733-747.

de Lyra, M. C. C. P., López-Baena, F. J., Madinabeitia, N., Vinardell, J. M., Espuny, M. R., Cubo, M. T., Bellogín, R. A., Ruiz-Sainz, J. E. \& Ollero, F. J. (2006). Inactivation of the Sinorhizobium fredii $\mathrm{HH} 103$ rhcJ gene abolishes nodulation outer proteins (Nops) secretion and decreases the symbiotic capacity with soybean. Int Microbiol 9, $125-133$.

Deakin, W. J., Marie, C., Saad, M. M., Krishnan, H. B. \& Brougthon, W. J. (2005). NopA is associated with cell surface appendages produced by the type III secretion system of Rhizobium sp. strain NGR234. Mol Plant Microbe Interact 18, 499-507.

Figurski, D. H. \& Helinski, D. R. (1979). Replication of an origincontaining derivative of plasmid RK2 dependent on a plasmid function provided in trans. Proc Natl Acad Sci $U S$ A 76, $1648-1652$.
Galan, J. E. \& Collmer, A. (1999). Type III secretion machines: bacterial devices for protein delivery into host cells. Science 284, 1322-1328.

Göttfert, M., Rothlisberger, S., Kundig, C., Beck, C., Marty, R. \& Hennecke, H. (2001). Potential symbiosis-specific genes uncovered by sequencing a 410-kilobase DNA region of the Bradyrhizobium japonicum chromosome. J Bacteriol 183, 1405-1412.

Kaneko, T., Nakamura, Y., Sato, S., Asamizu, E., Kato, T., Sasamoto, S., Watanabe, A., Idesawa, K., Ishihawa, A. \& other authors (2000). Complete genome structure of the nitrogen-fixing symbiotic bacterium Mesorhizobium loti. DNA Res 7, 331-338.

Krause, A., Doerfel, A. \& Göttfert, M. (2002). Mutational and transcriptional analysis of the type III secretion system of Bradyrhizobium japonicum. Mol Plant Microbe Interact 15, 1228-1235.

Krishnan, H. B. (2002). NolX of Sinorhizobium fredii USDA257, a type III-secreted protein involved in host range determination, is localized in the infection threads of cowpea (Vigna unguiculata [L.] Walp) and soybean (Glycine max [L.] Merr.) nodules. J Bacteriol 184, 831-839.

Krishnan, H. B., Kuo, C.-I. \& Pueppke, S. (1995). Elaboration of flavonoid-induced proteins by the nitrogen-fixing soybean symbiont Rhizobium fredii is regulated by both nodD1 and nodD2, and is dependent on the cultivar-specificity locus nolXWBTUV. Microbiology 141, 2245-2251.

Krishnan, H. B., Lorio, J., Kim, W. S., Jiang, G., Kim, K. Y., DeBoer, M. \& Pueppke, S. G. (2003). Extracellular proteins involved in soybean cultivar specific nodulation are associated with pilus-like appendages and exported by a type III protein secretion system in Sinorhizobium fredii USDA257. Mol Plant Microbe Interact 16, 617-625.

Laemmli, U. K. (1970). Cleavage of structural proteins during the assembly of the head of bacteriophage T4. Nature 227, 680-685.

Lamrabet, Y., Bellogín, R. A., Cubo, M. T., Espuny, M. R., Gil, A., Krishnan, H. B., Megías, M., Ollero, F. J., Pueppke, S. G. \& other authors (1999). Mutation in GDP-fucose synthesis genes of Sinorhizobium fredii alters Nod factors and significantly decreases competitiveness to nodulate soybeans. Mol Plant Microbe Interact 12, 207-217.

Lorio, J. C., Kim, W. S. \& Krishnan, H. B. (2004). NopB, a soybean cultivar-specificity protein from Sinorhizobium fredii USDA257, is a type III secreted protein. Mol Plant Microbe Interact 17, 1259-1268.

Madinabeitia, N., Bellogín, R. A., Buendía-Clavería, A. M., Camacho, M., Cubo, T., Espuny, M. R., Gil-Serrano, A. M., Lyra, M. C., Moussaid, A. \& other authors (2002). Sinorhizobium fredii $\mathrm{HH} 103$ has a truncated nolO gene due to a -1 frameshift mutation that is conserved among other geographically distant S. fredii strains. Mol Plant Microbe Interact 15, 150-159.

Marie, C., Deakin, W. J., Viprey, V., Kopcinska, J., Golinowski, W., Krishnan, H. B., Perret, X. \& Broughton, W. J. (2003). Characterization of Nops, nodulation outer proteins, secreted via the type III secretion system of NGR234. Mol Plant Microbe Interact 16, 743-751.

Marie, C., Deakin, W. J., Ojanen-Reuhs, T., Diallo, E., Reuhs, B., Broughton, W. J. \& Perret, X. (2004). TtsI, a key regulator of Rhizobium species NGR234 is required for type III-dependent protein secretion and synthesis of rhamnose-rich polysaccharides. Mol Plant Microbe Interact 17, 958-966.

Marschner, H. (1995). Mineral Nutrition of Higher Plants, 2nd edn. London: Academic Press.

Meinhardt, L. W., Krishnan, H. B., Balatti, P. A. \& Pueppke, S. G. (1993). Molecular cloning and characterization of a sym plasmid locus that regulates cultivar-specific nodulation of soybean by Rhizobium fredii USDA257. Mol Microbiol 9, 17-29. 
Miller, J. H. (1972). Experiments in Molecular Genetics. Cold Spring Harbor, NY: Cold Spring Harbor Laboratory.

Pallen, M. J., Chaudhuri, R. R. \& Henderson, I. R. (2003). Genomic analysis of secretion systems. Curr Opin Microbiol 6, 519-527.

Perret, X., Freiberg, C., Rosenthal, A., Broughton, W. J. \& Fellay, R. (1999). High-resolution transcriptional analysis of the symbiotic plasmid of Rhizobium sp. NGR234. Mol Microbiol 32, 415-425.

Perret, X., Staehelin, C. \& Broughton, W. J. (2000). Molecular basis of symbiotic promiscuity. Microbiol Mol Biol Rev 64, 180-201.

Prentki, P. \& Krisch, H. M. (1984). In vitro insertional mutagenesis with a selectable DNA fragment. Gene 29, 303-313.

Pueppke, S. G., Bolaños-Vasquez, M. C., Werner, D., Bec-Ferté, M., Promé, J. \& Krishnan, H. B. (1998). Release of flavonoids by the soybean cultivars McCall and Peking and their perception as signals by the nitrogen-fixing symbiont Sinorhizobium fredii. Plant Physiol 117, 599-608.

Rodrigues, J. A., López-Baena, F. J., Ollero, F. J., Vinardell, J. M., Espuny, M. R., Bellogín, R. A., Ruiz-Sainz, J. E., Thomas, J. R., Sumpton, D. \& other authors (2007). NopM and NopD are rhizobial nodulation outer proteins: identification using LC-MALDI and LCESI with a monolithic capillary column. J Proteome Res 6, 1029-1037.

Saad, M. M., Kobayashi, H., Marie, C., Brown, I. R., Mansfield, J. W., Broughton, W. J. \& Deakin, W. J. (2005). NopB, a type III secreted protein of Rhizobium sp. strain NGR234, is associated with pilus-like surface appendages. J Bacteriol 187, 1173-1181.

Sambrook, J., Fritsch, E. F. \& Maniatis, T. (1989). Molecular Cloning: a Laboratory Manual, 2nd edn. Cold Spring Harbor, NY: Cold Spring Harbor Laboratory.

Schäfer, A., Tauch, A., Jäger, W., Kalinowski, J., Thierbach, G. \& Pühler, A. (1994). Small mobilizable multi-purpose cloning vectors derived from the Escherichia coli plasmids pK18 and pK19: selection of defined deletions in the chromosome of Corynebacterium glutamicum. Gene 145, 69-73.
Simon, R. (1984). High frequency mobilization of Gram-negative bacterial replicons by the in vivo constructed Tn5-Mob transposon. Mol Gen Genet 196, 413-420.

Skorpil, P., Saad, M. M., Boukli, N. M., Kobayashi, H., Ares-Orpel, F., Brougthon, W. J. \& Deakin, W. J. (2005). NopP, a phosphorylated effector of Rhizobium sp. strain NGR234, is a major determinant of nodulation of the tropical legumes Flemingia congesta and Tephrosia vogelii. Mol Microbiol 57, 1304-1317.

Spaink, H. P., Okker, R. J. H., Wijffelman, C. A., Pees, E. \& Lugtenberg, B. J. J. (1987). Promoters in nodulation region of the Rhizobium leguminosarum Sym plasmid pRL1JI. Plant Mol Biol 9, 27-39.

Süss, C., Hempel, J., Zehner, S., Krause, A., Patschkowski, T. \& Göttfert, M. (2006). Identification of genistein-inducible and type IIIsecreted proteins of Bradyrhizobium japonicum. J Biotechnol 126, 69-77.

Vinardell, J. M., Ollero, F. J., Hidalgo, A., López-Baena, F. J., Medina, C., Ivanov-Vangelov, K., Parada, M., Madinabeitia, N., Espuny, M. R. \& other authors (2004a). NolR regulates diverse symbiotic signals of Sinorhizobium fredii HH103. Mol Plant Microbe Interact 17, 676-685.

Vinardell, J. M., López-Baena, F. J., Hidalgo, A., Ollero, F. J., Bellogín, R., Espuny, M. R., Temprano, F., Romero, F., Krishnan, H. B. \& other authors (2004b). The effect of FITA mutations on the symbiotic properties of Sinorhizobium fredii varies in a chromosomal-background-dependent manner. Arch Microbiol 181, 144-154.

Vincent, J. M. (1970). The modified Fåhraeus slide technique. In $A$ Manual for the Practical Study of Root Nodule Bacteria, appendix 3, pp. 144-145. Edited by J. M. Vincent. Oxford: Blackwell Scientific Publications.

Viprey, V., del Greco, A., Golinowski, W., Broughton, W. J. \& Perret, X. (1998). Symbiotic implications of type III protein secretion machinery in Rhizobium. Mol Microbiol 28, 1381-1389.

Edited by: H.-M. Fischer 